Prepared for the U.S. Department of Energy

under Contract DE-AC05-76RL01830

\title{
Bounding the marginal cost of producing potable water including the use of seawater desalinization as a backstop potable water production technology
}

JJ Dooley

April 2014

Pacific Northwest

NATIONAL LABORATORY

Proudly Operated by Battelle Since 1965 


\title{
DISCLAIMER
}

This report was prepared as an account of work sponsored by an agency of the United States Government. Neither the United States Government nor any agency thereof, nor Battelle Memorial Institute, nor any of their employees, makes any warranty, express or implied, or assumes any legal liability or responsibility for the accuracy, completeness, or usefulness of any information, apparatus, product, or process disclosed, or represents that its use would not infringe privately owned rights. Reference herein to any specific commercial product, process, or service by trade name, trademark, manufacturer, or otherwise does not necessarily constitute or imply its endorsement, recommendation, or favoring by the United States Government or any agency thereof, or Battelle Memorial Institute. The views and opinions of authors expressed herein do not necessarily state or reflect those of the United States Government or any agency thereof.

\author{
PACIFIC NORTHWEST NATIONAL LABORATORY \\ operated by \\ BATTELLE \\ for the \\ UNITED STATES DEPARTMENT OF ENERGY \\ under Contract DE-AC05-76RL01830
}

Printed in the United States of America
Available to DOE and DOE contractors from the Office of Scientific and Technical Information,
P.O. Box 62, Oak Ridge, TN 37831-0062;
ph: (865) 576-8401
fax: $(865)$ 576-5728
email: reports@adonis.osti.gov

\begin{abstract}
Available to the public from the National Technical Information Service, U.S. Department of Commerce, 5285 Port Royal Rd., Springfield, VA 22161 ph: (800) 553-6847 fax: $(703) 605-6900$ email: orders@ntis.fedworld.gov online ordering: http://www.ntis.gov/ordering.htm
\end{abstract}

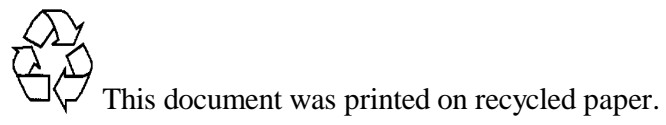




\section{Bounding the marginal cost of producing potable water including the use of seawater desalinization as a backstop potable water production technology}

JJ Dooley

April 2014

Prepared for the U.S. Department of Energy under Contract DE-AC05-76RL01830

Pacific Northwest National Laboratory

Richland, Washington 99352 


\begin{abstract}
The analysis presented in this technical report should allow for the creation of high, medium, and low cost potable water prices for GCAM. Seawater reverse osmosis (SWRO) based desalinization should act as a backstop for the cost of producing potable water (i.e., the literature seems clear that SWRO should establish an upper bound for the plant gate cost of producing potable water). Transporting water over significant distances and having to lift water to higher elevations to reach end-users can also have a significant impact on the cost of producing water. The three potable fresh water scenarios describe in this technical report are: low cost water scenario $\left(\$ 0.10 / \mathrm{m}^{3}\right)$; medium water cost scenario $\left(\$ 1.00 / \mathrm{m}^{3}\right)$; and high water cost scenario $\left(\$ 2.50 / \mathrm{m}^{3}\right)$.
\end{abstract}


1.0 OVERVIEW OF THREE GCAM WATER PRICE SCENARIOS

1.1 LOW COST WATER SCENARIO $\left(\$ 0.10 / \mathrm{M}^{3}\right)$

1.2 MEDIUM WATER COST SCENARIO $\left(\$ 1.00 / \mathrm{M}^{3}\right)$

1.3 HIGH WATER COST SCENARIO $\left(\$ 2.50 / \mathrm{M}^{3}\right)$

1.4 SHARED ASSUMPTIONS ACROSS ALL THREE WATER PRICE SCENARIOS

2.0 DEFINING WATER QUALITY TERMS

2.1 POTABLE WATER

2.2 FRESH WATER

2.3 BRACKISH WATER

2.4 SALINE WATER

3.0 MARGINAL COST OF PRODUCING POTABLE WATER

3.1 COSTS FOR BULK WATER TRANSPORT (E.G., VIA PIPELINE OR AQUEDUCT)

3.2 LITERATURE REVIEW OF WATER TREATMENT COSTS EXCLUSIVE OF SEAWATER DESALINIZATION

3.3 CuRRENT STATUS OF SEAWATER DESALINATION

3.3.1 THERMAL DESALINIZATION UNLIKELY TO BE DOMINANT FUTURE SEAWATER DESALINATION TECHNOLOGY

3.3.2 SEAWATER REVERSE OSMOSIS (SWRO): THE LIKELY DOMINANT FUTURE SEAWATER DESALINATION TECHNOLOGY

3.3.3 LITERATURE ESTIMATES OF THE COST OF PRODUCING POTABLE WATER VIA SWRO 


\subsection{Overview of Three GCAM Water Price Scenarios}

The analysis presented in this technical report should allow for the creation of high, medium, and low cost potable water prices for GCAM. Seawater reverse osmosis (SWRO) based desalinization should act as a backstop for the cost of producing potable water (i.e., the literature seems clear that SWRO should establish an upper bound for the plant gate cost of producing potable water). Transporting water over significant distances and having to lift water to higher elevations to reach end-users can also have a significant impact on the cost of producing water. A first order cut at these three GCAM water price scenarios and their associated story lines is as follows:

\subsection{Low cost water scenario $\left(\$ 0.10 / \mathrm{m}^{3}\right)$}

This low cost scenario (perhaps unrealistically low) assumes that the marginal cost of water is set by the cost of pumping fresh water from a shallow aquifer or a surface water body, with little or no treatment needed to make the water potable. Again the cost of transporting this "new" potable water and tying it into existing water distribution systems is small enough that it is assumed to be accounted for in the overall price of $\$ 0.10 / \mathrm{m}^{3}$. That is the cost here is basically for the capital cost of shallow wells (if needed) and the capital and electricity cost of pumping equipment.

\subsection{Medium water cost scenario $\left(\$ 1.00 / \mathrm{m}^{3}\right)$}

The central storyline for this water price scenario is that large scale deployment of seawater desalinization ${ }^{1}$ is not needed as society finds ways to increase the efficiency of water use, to recycle more water, and to use waste and effluent streams from various processes for feedstocks for more conventional water treatment. There are papers in the literature that speak directly to this idea of whether there is a price threshold where various substitute water supplies (including significant demand side management activities) come on line and whether that price threshold is significantly less than the cost of large scale deployment of seawater desalinization. The cost of transporting this "new" potable water and tying it into existing water distribution systems is small enough that it is assumed to be accounted for in the $\$ 1.00 / \mathrm{m}^{3}$ cost. Given the overlap between the cost of producing water from different systems, one could also interpret this scenario as allowing for large seawater desalinization but those plants would have to be very efficient to produce potable water within this price scenario.

${ }^{1}$ To be clear, desalinization of brackish waters (but not seawater) could take place in this medium water cost scenario as Ghaffour et al. (2013) note "brackish water cost is always lower than SWRO mainly due to lower salinity feed water which requires lower applied pressure and allows higher recovery. This causes a lower energy consumption per unit volume of water produced and a substantially lower investment cost." (Gray et al., 2011) notes that $77 \%$ of the installed desalinization 


\subsection{High water cost scenario $\left(\$ 2.50 / \mathrm{m}^{3}\right)$}

The key assumption in this water price scenario is that desalinated seawater which must be transported some distance inland where it then hooks up to an existing water distribution system sets the marginal cost for potable water. To be conservative (i.e., to err on the side of overstating the marginal cost), we will assume that the cost here is $\$ 2.50 / \mathrm{m}^{3}$. This equates to a world in which seawater is desalinated using current state of the art reverse osmosis plants and transporting the water a few hundred $\mathrm{km}$ inland and lifting the water $2-3 \mathrm{~km}$ in altitude.

\subsection{Shared assumptions across all three water price scenarios}

There are a number of underlying assumptions that are shared by all three of these draft water price scenarios that are worth stating explicitly so that we can see if these are appropriate or if the assumptions should be changed.

1. Potable water. The costs above are the marginal cost to produce potable water. The literature has different cost for various grades of grey water but the assumption here is that for the present GCAM is focused on modeling potable water.

2. All end users use potable water. As a first cut, these water price scenarios will be global (i.e., will not vary across the GCAM regions) and will be applicable to all water end use sectors. ${ }^{2}$ Regional and sector specific water prices could be constructed with further research. ${ }^{3}$

3. "Plant gate" water production cost. The term "marginal cost" here is meant to convey that these costs do not include expenditures for creating from scratch or extensively modernizing existing water end-use distribution systems. The only costs for moving water from the point of production to consumers in these cases would be the cost associated with tying the new water source into an existing water transport or distribution system (e.g., a major aqueduct). The cost of delivered water to a household water tap could be significantly higher than the costs described in these scenarios. ${ }^{4}$

${ }^{2}$ Greenlee et al. (2009) state that brackish waters can be used for agricultural irrigation and that depending on the crop waters up to 2000 TDS of chloride can be tolerated.

${ }^{3}$ For example, Ghaffour et al. (2013) state that Qatar and Kuwait are $100 \%$ reliant on desalinated water for all domestic and industrial applications.

${ }^{4}$ For example, Table 11 in Plappally and Lienhard (2012) provides data on the delivered cost of water to households in a number of major Asian cities. While Ghaffour et al. (2013) state "Cost of desalination commonly is not directly related to charges for delivered potable water charged by a utility or contractor." Mezher et al. (2011) provide a wealth of country specific data about installed desalinization capacity and expected growth. 
4. Very high capacity factors. It is assumed that these water treatment facilities operate at very high capacity factors (e.g., 90\%). As described below, a number of studies note that modern desalinization plants do not operate at anything close to their design capacities. These authors show that if these facilities do not operate near their design capacity the per unit (i.e., $\$ / \mathrm{m}^{3}$ ) cost of the potable water created can increase significantly (e.g., can increase the cost of the produced water by more than threefold).

5. Electricity is fuel of choice. As a simplifying assumption, it will be assumed that water treatment facilities use electricity purchased from the grid as the only energy input for these facilities. ${ }^{5}$

6. Neutral technological change. In looking at the literature and thinking about how the GCAM works, it is not immediately clearly how we should parameterize the marginal cost of this produced water over time. For the time being, the assumption here is that the real cost of producing the marginal unit of water in these three scenarios stays the same across the $21^{\text {st }}$ century. That is, it is assumed that cost savings from technological progress in treating or desalinating water are just enough to offset the increased cost associated with having to exploit more distant or lower grade water bodies. That is just the initial assumption for these draft water price scenarios. There are sound arguments that can be made that would result in a steadily increasing or a steadily decreasing marginal cost to produce potable water. Eventually we would want to model these water treatment technologies more explicitly within GCAM, which would allow for changes in the cost of electricity (electricity is the predominant energy used with water treatment facilities) to drive the cost of the produced water.

${ }^{5}$ Greenlee et al. (2009) describes a number of small scale facilities that use renewable energy in water treatment. Solar, wind, and geothermal systems have been mated to water treatment facilities in isolated areas. 


\subsection{Defining Water Quality Terms}

To be clear, this paper will used the following terminology when discussing various grades of source waters: potable, fresh, brackish and saline. Potable water and fresh water are not necessarily synonyms. Fresh water might still need some level of treatment to make it fit for human consumption. Please note these terms refer to water quality and not the source of the water, e.g., brackish water can come from a surface water body, the effluent from an industrial plant, runoff from agricultural fields, or certain deep underground aquifers.

\subsection{Potable water}

Potable water is defined as water that is ready for human consumption. This can include raw fresh water as defined below or it can include fresh water that has undergone some form of treatment. The USEPA and similar regulatory bodies around the world set limits for allowable levels a very wide range of contaminants that go far beyond simply a measure of the total dissolved solids (e.g., USEPA, 2009 lists the Maximum Contaminent Level for dozens of substances for drinking water). Greenlee et al. (2009) lists a number of jurisdictions that set TDS levels in the range of $250 \mathrm{mg} / \mathrm{l}$ to $500 \mathrm{mg} / \mathrm{l}$ for potable water. Greenlee et al. (2009) also note "most desalination facilities are designed to achieve a TDS of $500 \mathrm{mg} / \mathrm{L}$ or less.". TDS is a rough and imperfect measure of water quality when it comes to using the water for human consumption or for agriculture (e.g., Greenlee et al., 2009 gives boron as an example of a contaminent that is difficult to remove from brackish and saline waters and that has significant negative impacts on humans and agriculture if not removed before the water is consumed).

\subsection{Fresh water}

Fresh water is defined to have less than $1000 \mathrm{mg} / \mathrm{L}$ of salts or total dissolved solids (TDS), which is often written as $<1000$ TDS. Greenlee et al. (2009) note that many, states, nations and international organizations have definitions of fresh water that have TDS levels lower than this 1000 TDS level while some have a higher threshold. However, these authors note, "Above $1000 \mathrm{mg} / \mathrm{L}$, properties such as taste, color, corrosion propensity, and odor can be adversely affected."

\subsection{Brackish water}

Brackish water is defined to have $1000 \mathrm{mg} / \mathrm{L}<\mathrm{TDS}<10,000 \mathrm{mg} / \mathrm{L}$ (Greenlee et al., 2009). Brackish water that is desalinated for human consumption comes principally from estuaries and from deeper (i.e., not shallow) underground formations (Greenlee et al., 2009). In the United States, underground formations that contain less than 10,000 TDS are classified as underground sources of drinking water 
(USDW) and are subject to a number of protections under the federal Safe Drinking Water Act (SDWA) of 1974 (Davidson et al., 2009). ${ }^{6}$

\subsection{Saline water}

Saline water is defined as having TDS $>10,000 \mathrm{mg} / \mathrm{L}$ (Greenlee et al., 2009). Saline water encompasses both seawater as well as water taken from deep underground aquifers. Greenlee et al. (2009) state that most seawater is in the range of 30,000 45,000 TDS but that there are seawater reverse osmosis desalinization plants that treat feedwaters that range from 10,000-60,000 TDS. The Dead Sea has a reported TDS level of 275,000 mg/l (Greenlee et al., 2009). While Welch and Rychel (2004) report TDS levels of 400,000 mg/l for deep geologic saline waters that have been produced along with oil from wells in the Continental United States.

\subsection{Marginal cost of producing potable water}

The marginal cost of producing potable water consists of the costs of transporting the water to a point where it can tie into an existing water transport and delivery infrastructure and the cost of treating the water via a number of different processes. Since the cost of transporting water will apply regardless of what kind of water treatment process is used, transport costs will be discussed first.

\subsection{Costs for bulk water transport (e.g., via pipeline or aqueduct)}

In terms of modeling water production costs within the GCAM, it seems unlikely that we will explicitly attempt to model distances and elevations between source waters of different qualities and delivery of that water to distant users. And therefore the purpose of this section is to briefly summarize how the cost of moving water over distance and raising it up a given elevation affects the cost of producing the water so that we can make it clear to readers that we are aware of these costs and state how we have or have not taken them into account in our water modeling. We should not be silent as to what we are assuming about water transport as it is clear from the literature that this can be a consequential driver of overall delivered cost. For example, Zhou and Tol (2005) make the point that the cost of water transport also applies for moving fresh water over long distances and can in certain cases make desalinization cost competitive if fresh water has to be moved over very long distances. $^{7}$

${ }^{6}$ There is a general assumption around the world that brackish waters with TDS levels of less than $10,000 \mathrm{mg} / \mathrm{l}$ will be off limits in terms of being candidates for large scale $\mathrm{CO}_{2}$ disposal (Davidson et al., 2009).

${ }^{7}$ Shrestha et al. (2011) examine this tradeoff between transporting fresh water some significant distance (more than 400 miles in this case) and compared to desalinating local water for a specific case in the desert southwester USA and conclude that while the desalinization of local water is the cheaper option when 
Zhou and Tol (2005) make it clear that the cost of moving water over a relatively short vertical distance (in the case described in their paper as little as $100 \mathrm{~m}$ in elevation) can be roughly the same as the cost of moving the water $100 \mathrm{~km}$ over a level terrain. Table 4 in Zhou and Tol (2005), which is reproduced below as Table 1, vividly demonstrates this point in its calculation of the cost of desalinating seawater and delivering the potable water to a selection of the world's major cities. As can be seen from Table 1, the cost range is large and is bracketed by Tripoli (sea level and on the coast) on the low end at $\$ 1.11 / \mathrm{m}^{3}$ and Mexico City (225 km inland and 2500 meters above sea level) on the high end at $\$ 2.71 / \mathrm{m}^{3}$ (2010 US $\$$ ). ${ }^{8}$

measured solely on a $\$ / \mathrm{m}^{3}$ basis, desalinating this water requires more energy and has higher GHG emissions than transporting the fresh water over a long distance. ${ }^{8}$ All monetary cost figures summarized here that were taken from the literature have been converted to inflation adjusted 2010 US dollars using GDP deflators published by BEA (2010). If a given paper did not state what the currency year was for its reported cost figures, the author assumed that the currency year was the same as the year the paper was published. 
Table 1 Cost of desalinating seawater and delivering the resulting potable water to a selection of the world's largest cities (taken from Zhou and Tol, 2005 and converted to inflation adjusted 2010 US dollars by the author)

\begin{tabular}{|c|c|c|c|c|c|}
\hline & $\begin{array}{l}\text { Distance } \\
(\mathbf{k m})\end{array}$ & $\begin{array}{l}\text { Elevation } \\
(\mathbf{k m})\end{array}$ & $\begin{array}{l}\text { Transport } \\
\text { cost } \\
\left(2010 \$ / \mathrm{m}^{3}\right) \\
\end{array}$ & $\begin{array}{l}\text { Desalinization } \\
\text { cost } \\
\left(2010 \$ / \mathrm{m}^{3}\right)^{9} \\
\end{array}$ & $\begin{array}{l}\text { Total cost } \\
\left(2010 \$ / \mathrm{m}^{3}\right) \\
\end{array}$ \\
\hline Beijing, China & 135 & 0.1 & $\$ 0.14$ & $\$ 1.11$ & $\$ 1.25$ \\
\hline Delhi, India & 1050 & 0.5 & $\$ 1.00$ & $\$ 1.11$ & $\$ 2.11$ \\
\hline Bangkok, Thailand & 30 & 0.1 & $\$ 0.08$ & $\$ 1.11$ & $\$ 1.19$ \\
\hline Riyadh, Saudi Arabia & 350 & 0.75 & $\$ 0.67$ & $\$ 1.11$ & $\$ 1.78$ \\
\hline Harare, Zimbabwe & 430 & 1.5 & $\$ 1.15$ & $\$ 1.11$ & $\$ 2.26$ \\
\hline Crateus, Brazil & 240 & 0.35 & $\$ 0.37$ & $\$ 1.11$ & $\$ 1.48$ \\
\hline Ramallah, Palestine & 40 & 1 & $\$ 0.60$ & $\$ 1.11$ & $\$ 1.71$ \\
\hline Sana, Yemen & 135 & 2.5 & $\$ 1.53$ & $\$ 1.11$ & $\$ 2.64$ \\
\hline Mexico City, Mexico & 225 & 2.5 & $\$ 1.60$ & $\$ 1.11$ & $\$ 2.71$ \\
\hline Zaragoza, Spain & 163 & 0.5 & $\$ 0.40$ & $\$ 1.11$ & $\$ 1.51$ \\
\hline Phoenix, United States & 280 & 0.32 & $\$ 0.38$ & $\$ 1.11$ & $\$ 1.49$ \\
\hline Tripoli, Libya & 0 & 0 & $\$ 0.00$ & $\$ 1.11$ & $\$ 1.11$ \\
\hline
\end{tabular}

As a rule of thumb, Zhou and Tol (2005) offer the following "Transport costs are assumed to be 6 cents per $100 \mathrm{~km}$ horizontal transport plus 5 cents per $100 \mathrm{~m}$ vertical transport" (2005 US\$). ${ }^{10}$

\subsection{Literature review of water treatment costs exclusive of seawater desalinization}

Before examining the cost of seawater desalinization, which will serve as a backstop technology for the cost of producing water in the GCAM, we will first review published estimates of the cost of producing potable water from the literature.

${ }^{9}$ It is worth noting that Zhou and Tol (2005) assume that the cost of desalinating seawater in all of these locations is the same and is fixed at $\$ 1.00 / \mathrm{m}^{3}$ (in 2005 US\$) although it is clear that there are site specific factors that would certainly impact this cost component. Perhaps, more importantly these authors assume a $90 \%$ capacity factor for the desalinization plants they modeled which would seem to be overly optimistic based upon the case histories summarized by Cooley and Ajami (2012).

10 Plappally and Lienhard (2012) also summarize the cost of transporting water for a number of specific case studies described in the literature they survyed. Cooley and Ajami (2012) report that the cost for a ten mile pipeline to be $\$ 0.41 \mathrm{per}^{3}$ for the proposed Carlsbad Desalinization Plant. 
These cost estimates will be organized in ascending order. The point of listing these estimates for the cost of creating potable water from a large range of technologies and from different qualities of sources waters is to give the reader a better sense of the kinds of technologies and circumstances that correspond to producing potable water under the three GCAM water price scenarios listed at the start of this document. Table 2 summarizes a number of cost estimates from the literature on the marginal cost to produce potable water exclusive of the cost of seawater desalination which will be addressed in the next section.

It is clear from Table 2 that the cost of producing potable water is highly site specific and that these site specific factors will continue into the future. As noted by Greenlee et al. (2009) and much of the other literature surveyed here, there is a high degree of site specific factors that can significantly influence the cost of water treatment and that "the type of water (seawater or brackish water), as well as the plant size and the energy source, play major roles in the cost."

It is also clear from Table 2 that the costs listed here spill across all three of the GCAM price scenarios listed above: low cost water scenario $\left(\$ 0.10 / \mathrm{m}^{3}\right)$, medium water cost scenario $\left(\$ 1.00 / \mathrm{m}^{3}\right)$, and high water cost scenario $\left(\$ 2.50 / \mathrm{m}^{3}\right)$ and that is fine as those scenarios and their short descriptions were intentionally meant to be broad and were not intended to speak to specific circumstances or system configurations for producing potable water. However even after saying that it is clear that the Low Water Cost Scenario is consistent with a world in which minimal effort is required to exploit water sources and minimal treatment is needed to render these waters potable. It is also clear that the Medium Water Price Scenario encompasses a much broader set of circumstances and water treatment technologies but that for the most part the Medium Water Price Scenario is one in which existing technologies are used to treat fresh or brackish waters. It is also clear from Table 2 that water conservation and water efficiency measures are not likely to be utilized extensively in the Low Water Cost Scenario but that these more efficient water technologies could play a significant role in the Medium Water Price Scenario. 
Table 2: Cost to produce potable water from literature survey $\left(2010 \$ / \mathrm{m}^{3}\right)$ exclusive of costs for seawater desalinization

\begin{tabular}{|c|c|c|c|}
\hline & $\begin{array}{l}\text { Cost }\left(2010 \$ / \mathrm{m}^{3} \text { of }\right. \\
\text { potable water })\end{array}$ & Notes & Source \\
\hline $\begin{array}{l}\text { Ground water } \\
\text { (Global) }\end{array}$ & $\$ 0.01-\$ 0.20$ & $\begin{array}{l}\text { Global average cost for pumping } \\
\text { ground water to the surface }\end{array}$ & $\begin{array}{l}\text { Plappally and Lienhard } \\
\text { (2012) }\end{array}$ \\
\hline $\begin{array}{l}\text { Brackish } \\
\text { water (SoCal) }\end{array}$ & $\$ 0.14$ & $\begin{array}{l}\text { Treatment of brackishwater from } \\
\text { the Colorado River in Southern } \\
\text { California }\end{array}$ & Greenlee et al. (2009) \\
\hline $\begin{array}{l}\text { Conventional } \\
\text { water } \\
\text { treatment } \\
\text { (USA) }\end{array}$ & $\$ 0.34$ & & $\begin{array}{l}\text { Plappally and Lienhard } \\
\text { (2012) }\end{array}$ \\
\hline $\begin{array}{l}\text { Surface water } \\
\text { (SoCal) }\end{array}$ & $\$ 0.32-\$ 0.65$ & Cost for San Diego County & $\begin{array}{l}\text { Cooley and Ajami } \\
(2012)\end{array}$ \\
\hline $\begin{array}{l}\text { Ground and } \\
\text { surface water } \\
\text { (USA) }\end{array}$ & $\$ 0.40-\$ 0.75$ & $\begin{array}{l}\text { Average cost for producing } \\
\text { potable water (no transport or } \\
\text { distribution costs) for the USA }\end{array}$ & $\begin{array}{l}\text { Plappally and Lienhard } \\
\text { (2012) }\end{array}$ \\
\hline $\begin{array}{l}\text { Ground and } \\
\text { surface water } \\
\text { (Western } \\
\text { Australia) }\end{array}$ & $\$ 0.45-\$ 0.61$ & $\begin{array}{l}\text { Average cost for producing and } \\
\text { distributing potable water in } \\
\text { Western Australia }\end{array}$ & $\begin{array}{l}\text { Plappally and Lienhard } \\
\text { (2012) }\end{array}$ \\
\hline $\begin{array}{l}\text { Treated } \\
\text { municipal } \\
\text { water (SoCal) }\end{array}$ & $\$ 0.81$ & $\begin{array}{l}\text { Cost paid by water agencies for } \\
\text { treated water from the } \\
\text { Metropolitan Water District of } \\
\text { Southern California. }\end{array}$ & $\begin{array}{l}\text { Cooley and Ajami } \\
\text { (2012) }\end{array}$ \\
\hline $\begin{array}{l}\text { Ground } \\
\text { water(SoCal) }\end{array}$ & $\$ 0.30-\$ 0.89$ & Cost for San Diego County & $\begin{array}{l}\text { Cooley and Ajami } \\
(2012)\end{array}$ \\
\hline $\begin{array}{l}\text { Desalinating } \\
\text { brackish } \\
\text { agricultural } \\
\text { runoff water }\end{array}$ & $\$ 0.45-\$ 0.71$ & $\begin{array}{l}\text { Cost to produce potable water } \\
\text { from agricultural run off water } \\
\text { with TDS }=8500 \mathrm{mg} / \mathrm{l}\end{array}$ & Gray et al. (2011) \\
\hline $\begin{array}{l}\text { Brackish } \\
\text { water } \\
\text { desalinzation } \\
\text { (Texas) }\end{array}$ & $\$ 0.33-\$ 0.69$ & $\begin{array}{l}\text { Range of reported costs for six } \\
\text { operational brackish water } \\
\text { desalinization facilities in Texas }\end{array}$ & Gray et al. (2011) \\
\hline $\begin{array}{l}\text { Water } \\
\text { produced by } \\
\text { implementing } \\
\text { efficiency } \\
\text { measures } \\
\text { (SoCal) }\end{array}$ & $\$ 0.12-\$ 0.81$ & $\begin{array}{l}\text { Estimated cost for a variety of } \\
\text { "water conservation and } \\
\text { efficiency" measures }{ }^{11}\end{array}$ & $\begin{array}{l}\text { Cooley and Ajami } \\
\text { (2012) }\end{array}$ \\
\hline $\begin{array}{l}\text { Recycled } \\
\text { water (SoCal) }\end{array}$ & $\$ 0.97-\$ 1.46$ & $\begin{array}{l}\text { Cost to produce potable water } \\
\text { from various effluent streams }\end{array}$ & $\begin{array}{l}\text { Cooley and Ajami } \\
(2012)\end{array}$ \\
\hline $\begin{array}{l}\text { Brackish } \\
\text { water (SoCal) }\end{array}$ & $\$ 1.20-\$ 1.39$ & $\begin{array}{l}\text { Treatment of brackish water to } \\
\text { potable water }\end{array}$ & $\begin{array}{l}\text { Cooley and Ajami } \\
(2012)\end{array}$ \\
\hline
\end{tabular}

11 In a footnote, Cooley and Ajami (2012) offer the following elaboration on this reported water cost for San Diego County, "Cost estimates for water conservation and efficiency are based on costs to the water agency, e.g., estimated expenditures on educational initiatives or incentives for conservation measures divided by the cumulative water savings and do not include costs or savings to the customer." 


\begin{tabular}{|l|l|l|l|}
\hline Bottled water & $\$ 3000$ & $\begin{array}{l}\text { Assuming a } 500 \mathrm{ml} \text { bottle of water } \\
\text { costs } \$ 1.50 \text { from a vending } \\
\text { machine }\end{array}$ & \\
\hline
\end{tabular}

\subsection{Current Status of Seawater Desalination}

Ghaffour et al. (2013) report that global desalinization capacity is 66.4 million $\mathrm{m}^{3} /$ day increasing to 100 million $\mathrm{m}^{3}$ /day by 2015 . Of this total, $63.7 \%$ is produced by membrane-based processes with the remainder from thermal desalinization systems. Ghaffour et al. (2013) also report that the feed water for the existing global desaliniation fleet "is split with about 58.9\% from seawater and $21.2 \%$ from brackish groundwater sources, and the remaining percentage from surface water and saline wastewater."

\subsubsection{Thermal desalinization unlikely to be dominant future seawater desalination technology}

According to Elimelech and Phillip (2011a), the large majority of operational thermal desalinization plants are in the Middle East. These thermal desalinization plants are very energy and greenhouse gas intensive and it is unlikely that future desalinization facilities will use this antiquated technology. Greenlee et al. (2009) states that thermal desalinization requires 10 times as much electricity as a modern SWRO plant.

Ghaffour et al. (2013) is one of the few papers that sees a continuing role for thermal desalinization technologies in the Middle East and North Africa. They note that these systems are well established in this region, have a proven record of high reliability, and offer the potential for cogeneration by utilizing waste heat from a nearby thermal power plant. It is also important to note that Ghaffour et al. (2013) assessment of the continued attractiveness of thermal desalinization in this region of the world hinges on their assumption that energy costs are lower in this region of the world. Mezher et al. (2011) demonstrates this point vividly when they state the cost of desalinating seawater is $\$ 1 / \mathrm{m}^{3}$ if one assumes it uses oil that is heavily subsidized and only costs $\$ 20 / \mathrm{bbl}$ but that same plant would produce water closer to $\$ 4 / \mathrm{m}^{3}$ if the cost of oil was $\$ 100 / \mathrm{bbl}$.

\subsubsection{Seawater Reverse Osmosis (SWRO): The likely dominant future seawater desalination technology}

Elimelech and Phillip (2011a) report "the vast majority of desalination plants constructed in the past two decades, as well as future planned facilities, are based on reverse osmosis technology." The focus of these notes will therefore be on characterizing reverse osmosis plants which carries with it an implicit assumption that new desalinization facilities, whether new greenfield or refurbishment of existing facilities, will be done using membrane-based systems. 
Many authors note that the large growth in installed desalinization capacity around the world and the decisive shift to membrane based systems is the result of the significant technological progress that has occurred in the last 2-3 decades for membrane-based desalinization (Cooley and Ajami, 2012; Elimelech and Phillip, 2011a; Ghaffour et al., 2013; Zhou and Tol, 2005). Ghaffour et al. (2013) note that 42 out of 71 of the world's largest cities that are already water stressed are along coasts and that $39 \%$ of humanity lives within 100 miles of a coast as evidence for the continued expansion of reverse osmosis desalinization.

For the purposes of modeling desalinization within GCAM, membrane based desalinization will be treated as one aggregate technology although the literature certainly reports on a number of discrete membrane based systems and the market niches they are best suited to address (Elimelech and Phillip, 2011a; Ghaffour et al., 2013; Macedonio and Drioli, 2010).

\subsubsection{Literature estimates of the cost of producing potable water via SWRO}

Table 3 summarizes a number of cost estimates from the literature on the marginal cost to produce potable water from SWRO systems. Just as with Table 2, these cost estimates for SWRO systems will be organized in descending order. The point of listing these various estimates is to give the reader a better sense of the kinds of technologies and circumstances that correspond to producing potable water under the three GCAM water price scenarios listed at the start of this document. 
Table 3 Estimates of SWRO produced potable water $\left(2010 \$ / \mathrm{m}^{3}\right)$

\begin{tabular}{|c|c|c|c|}
\hline & $\begin{array}{l}\text { Cost }\left(2010 \$ / \mathrm{m}^{3} \text { of }\right. \\
\text { potable water })\end{array}$ & Notes & Source \\
\hline $\begin{array}{l}\text { SWRO of } \\
\text { water from } \\
\text { the } \\
\text { Mediterranean } \\
\text { Sea }\end{array}$ & $\$ 0.60$ & $\begin{array}{l}\text { Ashkelon (Israel) seawater } \\
\text { desalinization plant }\end{array}$ & $\begin{array}{l}\text { (Greenlee et al., } \\
\text { 2009) }\end{array}$ \\
\hline $\begin{array}{l}\text { Water } \\
\text { produced by } \\
\text { implementing } \\
\text { efficiency } \\
\text { measures } \\
\text { (SoCal) }\end{array}$ & $\$ 0.12-\$ 0.81$ & $\begin{array}{l}\text { Estimated cost for a variety of } \\
\text { "water conservation and } \\
\text { efficiency" measures }{ }^{12}\end{array}$ & $\begin{array}{l}\text { Cooley and Ajami } \\
(2012)\end{array}$ \\
\hline $\begin{array}{l}\text { Tampa Bay } \\
\text { SWRO }\end{array}$ & $\$ 0.93$ & & $\begin{array}{l}\text { Cooley and Ajami } \\
(2012)\end{array}$ \\
\hline $\begin{array}{l}\text { High level } \\
\text { engineering } \\
\text { estimate for } \\
\text { SWRO (global) }\end{array}$ & $\$ 1.00-\$ 1.11$ & $\begin{array}{l}\text { Generally accepted high level } \\
\text { global average for SW }\end{array}$ & $\begin{array}{l}\text { Ghaffour et al. } \\
\text { (2013) } \\
\text { Zhou and Tol } \\
(2005)\end{array}$ \\
\hline $\begin{array}{l}\text { Recycled } \\
\text { water (SoCal) }\end{array}$ & $\$ 0.97-\$ 1.46$ & $\begin{array}{l}\text { Cost to produce potable water } \\
\text { from various effluent streams }\end{array}$ & $\begin{array}{l}\text { Cooley and Ajami } \\
(2012)\end{array}$ \\
\hline $\begin{array}{l}\text { Brackish } \\
\text { water (SoCal) }\end{array}$ & $\$ 1.20-\$ 1.39$ & $\begin{array}{l}\text { Treatment of brackish water to } \\
\text { potable water }\end{array}$ & $\begin{array}{l}\text { Cooley and Ajami } \\
(2012)\end{array}$ \\
\hline $\begin{array}{l}\text { Gold Coast } \\
\text { (Australia) } \\
\text { SWRO }\end{array}$ & $\$ 1.63$ & & $\begin{array}{l}\text { Cooley and Ajami } \\
(2012)\end{array}$ \\
\hline $\begin{array}{l}\text { Kurnell SWRO } \\
\text { (Sydney, } \\
\text { Australia) } \\
\end{array}$ & $\$ 2.00$ & & $\begin{array}{l}\text { Cooley and Ajami } \\
\text { (2012) }\end{array}$ \\
\hline $\begin{array}{l}\text { Seawater } \\
\text { Desalination } \\
\text { (California) }\end{array}$ & $\$ 1.54-\$ 2.43$ & $\begin{array}{l}\text { This is reported as the current } \\
\text { cost of seawater desalination } \\
\text { along the California coast. }\end{array}$ & $\begin{array}{l}\text { Cooley and Ajami } \\
(2012)\end{array}$ \\
\hline Bottled water & $\$ 3000$ & $\begin{array}{l}\text { Assuming a } 500 \mathrm{ml} \text { bottle of water } \\
\text { costs } \$ 1.50 \text { from a vending } \\
\text { machine }\end{array}$ & \\
\hline
\end{tabular}

A number of the papers reviewed for this analysis, report a current cost for seawater reverse osmosis plants of $\$ 1.00 / \mathrm{m}^{3}$ (Ghaffour et al., 2013; Zhou and Tol, 2005). This seems to be a generally accepted round number for initial high-level

12 In a footnote, Cooley and Ajami (2012) offer the following elaboration on this reported water cost for San Diego County, "Cost estimates for water conservation and efficiency are based on costs to the water agency, e.g., estimated expenditures on educational initiatives or incentives for conservation measures divided by the cumulative water savings and do not include costs or savings to the customer." 
assessments of the cost of developing various water alternative supplies. But this nice round $\$ 1.00 / \mathrm{m}^{3}$ figure seems to not account for a number of additional process steps that might be encountered in the real world, which would push the cost of SWRO produced potable water above this threshold. For example,

- While the cost and performance of SWRO systems have improved dramatically over the past 30 years, a number of authors are skeptical as to whether this trend can continue at this pace. Reverse osmosis plants built in the 1980s might have operated at $20 \mathrm{kWh} / \mathrm{m}^{3}$, while facilities built in 2000 consumed only $3.5 \mathrm{kWh} / \mathrm{m}^{3}$ (Elimelech and Phillip, 2011b). Ghaffour et al. (2013) state "desalinated water cost will not reduce further at the same rate of decline" as that which has characterized the decline in prices over the past couple of decades.

- As noted earlier, Mezher et al. (2011) demonstrate that if desalination plants have to pay market prices for their energy inputs that could significantly increase the cost of the produced potable water. Cooley and Ajami (2012) touch upon a related point when they observe that note that SWRO produced water is still relatively expensive and that the costs could increase if energy prices were to rise or if the desalinization plant is run at less than full capacity.

- Cooley and Ajami (2012) examine in some detail the impact of operating SWRO facilities at low capacity factors and their modeling shows that depending upon whether the modeled SWRO facility is operating at $100 \%$ or $20 \%$ capacity factor can increase the cost of produced water from $\$ 2.17 / \mathrm{m} 3$ to $\$ 7.96 / \mathrm{m} 3$

- Ghaffour et al. (2013) SWRO facilities in the Arabian Gulf typically need to have "advanced pretreatment systems" to protect the membranes from the harsher waters found here.

- Gray et al. (2011) provide data that show that in certain locales within the US the cost of discharging the concentrated waste brine via disposal wells can account for a majority of the cost of producing the desalinated potable water. Greenlee et al. (2009) cite costs as high as $\$ 2.64 / \mathrm{m} 3$ for brine disposal via deep well injection and costs as high as $\$ 10.04 / \mathrm{m} 3$ for disposal of brine via evaporation ponds.

- Ghaffour et al. (2013) note that some projects must also include "extraordinary costs such as complicated offshore intakes or extensive environmental mitigation measures" which will drive up the per unit cost of the delivered potable water. ${ }^{13}$

${ }^{13}$ In their review article, Elimelech and Phillip (2011a) state that there are no conclusive data about the detrimental impacts of releasing this higher brine water (along with a number of chemicals used to maintain the reverse osmosis plant) into the ocean. 
Cooley and Ajami (2012) make the case that desalinization plants face significant demand risks that are under appreciated. They note that 4 out of 6 desalinization plants built in Australia since 2006 are in standby mode and are not operating and that the Tampa Bay Desalination Plant operates well below its design capacity. These authors focus quite a bit of attention on how the per unit cost of produced water can change for the worse if these plants are not run at full capacity. They note that desalinization plants are often built at a scale commensurate with peak water demand in an effort to capture economies of scale but that once the severe drought is over that motivated the construction of desalinization plant the plant is unlikely to operate at this design capacity. In the future, we might want to think about the role that water saving technologies could play and how that would impact the deployment of desalinization.

But the point worth stressing here is that much of the literature reviewed here is quite bullish on SWRO in terms of its current cost and potential lower costs in the future and therefore we should be aware that a cost above $\$ 1.00 / \mathrm{m}^{3}$ could strike some readers and reviewers as overly pessimistic.

\subsubsection{Initial assessment of energy, capital and O\&M details for desalinization plants}

Reverse osmosis plants built in the $1980 \mathrm{~s}$ might have operated at $20 \mathrm{kWh} / \mathrm{m}^{3}$, while facilities built in 2000 consumed only $3.5 \mathrm{kWh} / \mathrm{m}^{3}$ (Elimelech and Phillip, 2011b). ${ }^{14}$ According to these researchers, the current state of the art for large scale commercial seawater desalinization plants are seawater reverse osmosis (SWRO) desalination plants, with energy consumption as low as $2 \mathrm{kWh} / \mathrm{m}^{3}$, and therefore reverse osmosis will be the focus here..$^{15}$ In their article, Elimelech and Phillip (2011a) go to great lengths to establish that current SWRO plants are already extremely energy efficient and that any further reductions in energy use are likely to be marginal. To wit, in summarizing this argument the authors state "The energy demand for seawater desalination by state-of-the-art reverse osmosis is within a factor of 2 of the theoretical minimum energy for desalination, and is only $25 \%$ higher than the practical minimum energy for desalination for an ideal reverse osmosis stage." 16

${ }^{14}$ The units above are worth describing in a bit more detail. The figure $3.5 \mathrm{kWh} / \mathrm{m} 3$ describes the electricity used for pumps for a reverse osmosis plant operating at $50 \%$ efficiency. In this context $50 \%$ efficiency means that half of the intake water is converted to potable drinking water and the remainder is returned to the ocean at a higher salinity than the original intake water.

15 In the main paper, Elimelech and Phillip (2011a) state that "current state-of-theart SWRO plants consume between 3 and $4 \mathrm{kWh} / \mathrm{m} 3$ " but in the supplemental information they provide this $2 \mathrm{kWh} / \mathrm{m} 3$ figure and describe it as "today's" power consumption(Elimelech and Phillip, 2011b). To be conservative, we might want to use the $4 \mathrm{kWh} / \mathrm{m} 3$ figure.

${ }^{16}$ They do note that there is potential to reduce the energy consumed by various pre and post treatment process and suggest that future research be directed in this 
Greenlee et al. (2009) and other authors have noted that energy recovery systems are often incorporated into modern RO facilities which helps lower the net power consumption of these facilities. Mezher et al. (2011) note that in many countries and in particular in the UAE low pressure/temperature steam from power is often used as a heat source for desalinization plants. Utilizing this cogeneration heat lowers the specific energy of these desalinization plants.

In their assessment, Cooley and Ajami (2012) state that for a typical desalinization plant annual costs are apportioned as follows: $37 \%$ capital costs (including servicing debt), 36\% energy cost, 10\% fixed non-energy O\&M costs, and 17\% non-energy O\&M costs. Zhou and Tol (2005) provide a similar disaggregation for only the variable costs for thermal desalinization plants of roughly $87 \%$ energy cost, $5 \%$ fixed non-energy $0 \& \mathrm{M}$ costs (i.e., chemicals), and 8\% non-energy $0 \& \mathrm{M}$ costs (i.e., labor). In their analysis, Zhou and Tol (2005) assume that 40\% of annual costs are for capital costs (including servicing debt) and 60\% are for the above enumerated variable costs.

aspect of the SWRO facility rather than trying to incrementally improve the already efficient $r$ 


\subsection{References}

BEA, 2010. Table 1.1.9. Implicit Price Deflators for Gross Domestic Product, August 27, 2010 ed. Bureau of Economic Analysis, US Department of Commerce.

Cooley, H., Ajami, N., 2012. Key Issues for Seawater Desalination in California: Cost and Financing. Pacific Institute, Oakland, California, p. 48.

Davidson, C., Dooley, J., Dahowski, R., 2009. Assessing the impacts of future demand for saline groundwater on commercial deployment of CCS in the United States. Energy Procedia 1, 1949-1956.

Elimelech, M., Phillip, W.A., 2011a. The Future of Seawater Desalination: Energy, Technology, and the Environment. Science 333, 712-717.

Elimelech, M., Phillip, W.A., 2011b. Supporting Online Material: The Future of Seawater Desalination: Energy, Technology, and the Environment. Science $333,8$.

Ghaffour, N., Missimer, T.M., Amy, G.L., 2013. Technical review and evaluation of the economics of water desalination: Current and future challenges for better water supply sustainability. Desalination 309, 197-207.

Gray, S., Semiat, R., Duke, M., Rahardianto, A., Cohen, Y., 2011. 4.04 - Seawater Use and Desalination Technology, in: Editor-in-Chief: Peter, W. (Ed.), Treatise on Water Science. Elsevier, Oxford, pp. 73-109.

Greenlee, L.F., Lawler, D.F., Freeman, B.D., Marrot, B., Moulin, P., 2009. Reverse osmosis desalination: Water sources, technology, and today's challenges. Water Research 43, 2317-2348.

Macedonio, F., Drioli, E., 2010. 4.09 - Membrane Systems for Seawater and Brackish Water Desalination, in: Editor-in-Chief: Enrico, D., Lidietta, G. (Eds.), Comprehensive Membrane Science and Engineering. Elsevier, Oxford, pp. 241-257.

Mezher, T., Fath, H., Abbas, Z., Khaled, A., 2011. Techno-economic assessment and environmental impacts of desalination technologies. Desalination 266, 263273.

Plappally, A.K., Lienhard, J.H., 2012. Costs for water supply, treatment, end-use and reclamation. Desalination and Water Treatment 51, 200-232.

Shrestha, E., Ahmad, S., Johnson, W., Shrestha, P., Batista, J.R., 2011. Carbon footprint of water conveyance versus desalination as alternatives to expand water supply. Desalination 280, 33-43.

USEPA, 2009. National Primary Drinking Water Regulations. United States Environmental Protection Agency, Washington, DC, p. 6.

Welch, R.A., Rychel, D.F., 2004. Produced Water from Oil and Gas Operations in the Onshore Lower 48 States. Northrop Grumman Mission Systems, Information \& Technical Services Division, Tulsa, Oklahoma, p. 100.

Zhou, Y., Tol, R.S.J., 2005. Evaluating the costs of desalination and water transport. Water Resources Research 41, W03003. 